\title{
エ学的近似を用いたナトリウムー水反応ジェット挙動 評価用粒子法コードの研究
}

\author{
小坂 亘 ${ }^{* 1}$, 内堀 昭寛 ${ }^{* 1}$, 柳沢 秀樹 ${ }^{* 2}$, 高田 孝*3, 張 承賢 ${ }^{* 4}$
}

\section{Study on sodium-water reaction jet evaluation model based on engineering approaches with particle method}

\author{
Wataru KOSAKA ${ }^{* 1}$, Akihiro UCHIBORI ${ }^{* 1}$, Hideki YANAGISAWA ${ }^{* 2}$, \\ Takashi TAKATA ${ }^{* 3}$ and Sunghyon $\mathrm{JANG}^{* 4}$ \\ ${ }^{* 1}$ Japan Atomic Energy Agency \\ 4002 Narita-cho, Oarai-mati, Higashi-Ibaraki-gun, Ibaraki 311-1393, Japan \\ ${ }^{* 2}$ NESI Corporation \\ 4002 Narita-cho, Oarai-mati, Higashi-Ibaraki-gun, Ibaraki 311-1313, Japan \\ *3 Japan Atomic Energy Agency \\ 4002 Narita-cho, Oarai-mati, Higashi-Ibaraki-gun, Ibaraki 311-1393, Japan \\ (Current affiliation: The University of Tokyo \\ 7-3-1 Hongo, Bunkyo-ku, Tokyo 113-8656, Japan) \\ ${ }^{*} 4$ The University of Tokyo \\ (Current affiliation: Hokkaido University \\ Kita 13, Nishi 8, Kita-ku, Sapporo, Hokkaido 060-8628, Japan)
}

Received: 1 October 2021; Revised: 22 November 2021; Accepted: 28 December 2021

\begin{abstract}
If pressurized water/water-vapor leaks from a heat transfer tube in a steam generator (SG) in a sodium-cooled fast reactor, the leakage forms high-velocity, high-temperature, and corrosive jet due to the pressure difference and sodium-water reaction. It would damage the other tubes and might propagate the tube failure in a SG. Thus, it is important to evaluate the effect of the tube failure propagation for safety assessment of a sodium-cooled fast reactor. The computational code LEAP-III can evaluate water leak rate during the tube failure propagation with short calculation time, since it consists of empirical formulae and one-dimensional equations of conservation. One of its models, the temperature distribution evaluation model, evaluates the temperature distribution in SG as circular arc isolines determined by experiments and preliminary analyses instead of complicated real distribution. Although this model has advantages of short calculation time and good agreement about maximum temperature, it provides broader high temperature region than the real one in some case. In order to improve this model to get more realistic temperature distribution, we have developed the Lagrangian particle method based on engineering approaches. In this study, we have focused on evaluating gas flow in a tube bundle system and constructed new models for the gas-particles behavior around a tube to evaluate void fraction distribution near the tube. Through the test analysis simulating vapor discharge in one target tube system and comparison with an existing computational fluid dynamics code, SERAPHIM, it was confirmed that basic behaviors of these models, which is the particles spread out around the target tube without significant inflow into the tube inside, and finally these went along the buoyancy force direction.
\end{abstract}

Keywords : Sodium-cooled fast reactor, Steam generator, LEAP-III, Lagrangian particle method, Engineering approach, Sodium-water reaction

No.21-00310 [DOI:10.1299/transjsme.21-00310], J-STAGE Advance Publication date : 13 January, 2022

本論文は，第25回動力・エネルギー技術シンポジウム 講演論文集(2021), No.A133の掲載内容に基づいた論文である.

*1 正員, 日本原子力研究開発機構（广311-1393 茨城県東茨城郡大洗町成田町 4002）

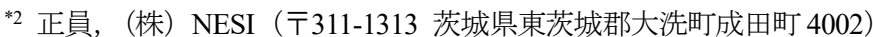

*3 正員, 日本原子力研究開発機構（現 東京大学大学院工学系研究科 $\overline{1} 113-8656$ 東京都文京区本郷 7-3-1)

${ }^{* 4}$ 東京大学大学院工学系研究科 (現 北海道大学大学院工学研究院 $\bar{T} 060-8628$ 北海道札幌市北区北 13 条西 8 丁目)

E-mail of corresponding author: kosaka.wataru@jaea.go.jp 


\section{1. 緒言}

ナトリウム（Na）冷却型高速炉の安全性解析において, 蒸気発生器（Steam generator, SG）の伝熱管破損時に生 じえる $\mathrm{Na}$ 一水反応現象の評価は重要である. 図 1 に SG 内の伝熱管破損伝播事象についての模式図を示す. SG 内部の伝熱管から高圧の水あるいは水蒸気が漏えいした場合，低圧の周囲 $\mathrm{Na}$ と激しく化学反応して高流速・高 温の反応性ジェットが形成される。このジェットは隣接しているほかの伝熱管に対して機械的・熱的負荷を加え る。その結果，管壁面が損耗され貫通に至るウェステージ型破損，あるいは加熱による強度低下で破裂に至る高 温ラプチャー型破損により新たな伝熱管破損が発生し，連鎖的に漏えいの規模が拡大していく可能性がある. こ の伝熱管破損伝播事象が進展し続けた場合, 水リーク率増加と $\mathrm{Na}$ 一水反応現象により 2 次冷却系内の圧力が上昇 していく.したがって, 1 次一2 次系バウンダリの健全性を確保する観点で破損伝播の進展を把握する必要がある.

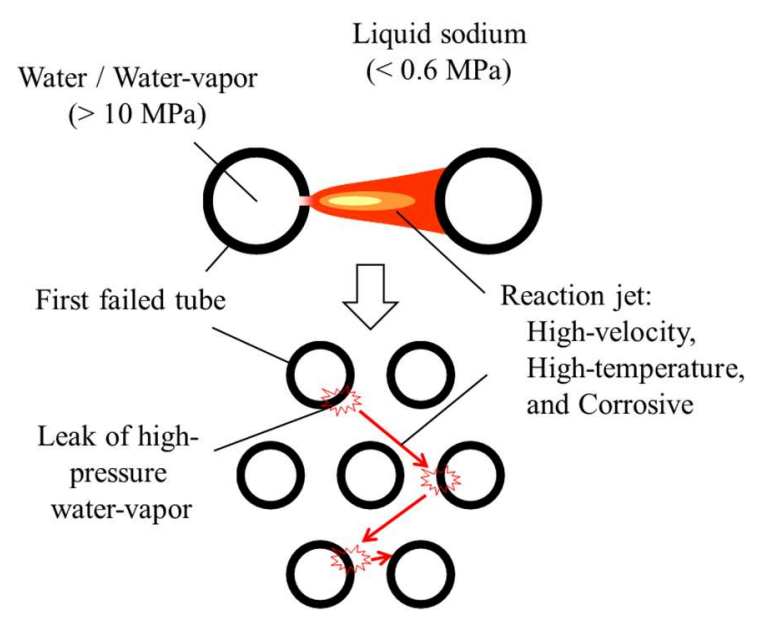

Fig. 1 Tube failure propagation. Pressurized water/water-vapor leaks from a microscopic crack on the first failed tube, and then it forms high-velocity, high-temperature, and corrosive jet due to the difference in pressure inside water and outside liquid sodium and sodium-water chemical reaction. This jet damages and may cause break the adjacent tube, and then water leak will be enlarged.

噴出孔周りの局所的な $\mathrm{Na}$ 一水反応ジェット挙動を詳細に評価するため, 高田らにより化学反応および圧縮性を 考慮した機構論的多次元多相流解析コード SERAPHIM が開発された（高田他，2002）。近年においても非構造メ ッシュへの対応などの精度向上や適用性拡張に向けた研究開発が続けられている (Uchibori et al., 2019).一方で, SG やプラント規模での安全性評価のため, 数值解析コード LEAP-III が開発されてきた (内堀他, 2017). LEAP-III は $\mathrm{Na}$ 一水反応ジェットを含めた伝熱管破損伝播における様々な事象（伝熱管への熱輸送やウェステージ，高温 プチャーなど）を考慮して, 高圧水/水蒸気の漏洩開始から事象収束するまでの長時間事象進展に伴う水リーク率 を評価する．長時間事象進展およびプラント全体という大きな系において様々な想定事象に対する安全性を評価 するために，計算コストへの制約があり，LEAP-III は保守性を担保しつつも低計算コストな簡略化されたモデル で構成されている. 以上のように, SERAPHIM と LEAP-III は計算コストと解析対象の範囲や精度とのバランス の取り方について設計思想の段階から異なっている.

LEAP-III は低計算コストで伝熱管破損伝播に関する一連の事象進展を解析可能という利点から, 新規 SG の設 計ツールとしての活用が期待される. 一方で, 伝熱管破損本数を実験結果より多く評価するなど, 過度な保守性 を示す場合がある (内堀他, 2017). この保守性を適正化する狙いで, 構成モデルのひとつである反応ジェット温 度分布評価モデルに注目した. 既存のモデルでは, 図 2 のような温度等值線群を SG 内の反応ジェットにより形 成される温度分布とみなす。これらの等值線群は, 自由噴流時における反応物質（水）の濃度分布から得られた 反応ジェットの界面形状を表す式（根井，堀，1977）に対して，水側条件や管束部分の影響を考慮するためのパ ラメータを加えた半経験的な評価式により決定される（内堀他，2017). 実験結果や数值解析結果を包含するよう にこれらパラメータを設定しておくことで, LEAP-III 実行時には任意の位置の局所温度を内挿計算から直ちに求 
めることができる．低計算コストという利点以外にも最高温度がよく一致するという利点もあるが，包含するよ うに等值線を設定するという性質上，実際の状況に比べて高温領域を過大に評価するという課題も存在する.

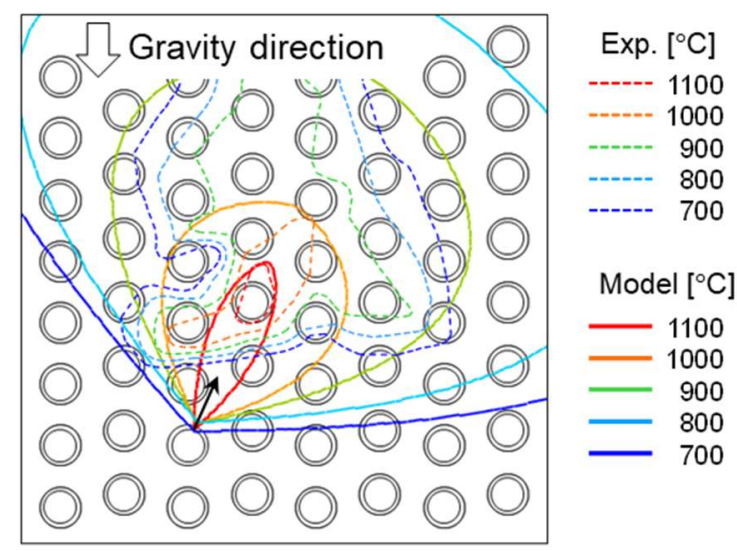

Fig. 2 Reaction jet temperature isolines by experiment and model in tube bundle system. The dashed lines show experimental data, and the solid lines are given by a semi-empirical correlation formula.

反応ジェット温度分布評価モデルの精度向上のために SERAPHIM そのものの取り入れることは，上述したよ うに使用用途の違いから LEAP-III に比べて桁違いに多くの計算時間を必要とするため, LEAP-III を安全性評価や 設計ツールとして使用する観点で適当ではない. 加えて, 2 次リーク発生以降の複数ジェットの取り扱いは粒子 法の方が容易である. そのため, 既存の評価手法より現実的な分布を与え，かつLEAP-III の低計算コストという 利点を損なわない評価手法として, 粒子法をべースに解析手法の開発が行われてきた。この粒子法コードでは, 噴出水蒸気のみをラグランジュ粒子の集団としてニュートンの運動方程式により時間発展を求める (Uchibori et al., 2020)．多相流においてジェットが受ける影響は，粒子に作用寸る力として近似的に表現される. ジェットの 温度変化を評価するため, 化学反応の影響を取り入れる検討も始められている（Kosaka et al., 2021）.

本粒子法において，伝熱管近傍でのジェットの流体挙動を模擬するため，伝熱管近傍にポテンシャルおよび粒 子一伝熱管相互作用力を与えている. 現在のところ, このポテンシャルとして暫定的に伝熱管中心から広がる Lennard-Jones ポテンシャルを用いている. 本論文では, 暫定的なモデルの代わりに，伝熱管近傍での流体挙動を 簡潔に模擬するために考案したモデルについて述べる. モデルの基本的機能を確認するため, 化学反応を無効と し，体系内にターゲット管が 1 本のみ存在する設定（単ターゲット管体系）を課してテスト解析を実施し，本粒 子法コードによる解析結果と, SERAPHIMによる解析結果とを比較した。

\section{2. ラグランジュ粒子法コード}

\section{$2 \cdot 1$ 基礎方程式}

本粒子法コードでは, 液相 $\mathrm{Na}$ 中における水蒸気の流れはラグランジュ粒子の集団で表現され, それぞれの粒 子は Newton の運動方程式（1）に従って時間発展する.

$$
\frac{d \mathbf{u}_{g}}{d t}=-\frac{\rho_{l}-\rho_{g}}{\rho_{g}} \mathbf{g}+\mathbf{f}_{\mathrm{d}}+\mathbf{f}_{\mathrm{pt}}
$$

ここで，下付きの $g, l$ はそれぞれ気相成分，液相成分を表す。 $\mathbf{u}_{g}[\mathrm{~m} / \mathrm{s}]$ は気相粒子の速度，t $\left.t \mathrm{~s}\right]$ は時刻, $\mathbf{g}\left[\mathrm{m} / \mathrm{s}^{2}\right]$ は 重力加速度, $\rho\left[\mathrm{kg} / \mathrm{m}^{3}\right]$ は密度である. 右辺の第 1 項は浮力を表す. 第 2 項の $\mathbf{f}_{\mathrm{d}}[\mathrm{N} / \mathrm{kg}]$ は気液相間抗力を表し, 式(2) で示される Autruffe モデル（Autruffe et al., 1979）を用いた.

$$
\mathbf{f}_{\mathrm{d}}=\frac{4.31}{2 D_{h}} \rho_{g}\left|\mathbf{u}_{g}-\mathbf{u}_{l}\right|\left(\mathbf{u}_{g}-\mathbf{u}_{l}\right)\left\{\left(1-\alpha_{g}\right)\left[1+75\left(1-\alpha_{g}\right)\right]\right\}^{0.95}
$$


ここで， $\alpha_{g}[-]$ は気相ボイド率， $D_{h}[\mathrm{~m}]$ は代表寸法を表す.このモデルは SERAPHIM においても使用されており， Edwards pipe blow down ベンチマーク問題を用いた検証解析で実験結果をおおむね再現できたことが示されてい る（高田他，2002）。液相 $\mathrm{Na}$ の速度 $\mathbf{u}_{l}$ について，本粒子法では簡単のため解析条件にて与えた值で一様かつ一 定と仮定した. 物理的には気液間の相互作用により $\mathbf{u}_{l}$ も時間発展するが，水蒸気と液相 $\mathrm{Na}$ の密度差が大きいた めに $\mathbf{u}_{l}$ の変化は無視できるとした．簡単のため $\rho_{l}$ は初期值で一定であり, 系内の液相 $\mathrm{Na}$ 質量は保存する.

式(2)で用いるボイド率を定義するため, 解析空間内に等間隔メッシュを設定した. 本手法は2 次元解析であり, メッシュに含まれる気相面積（粒子面積の総和）とメッシュ面積の比でボイド率を定義できるが，粒子同士の重 なりが生じた場合にこの比が 1 を超えることがある. そこで, 最小值を取る処理 $\min ($ )を用いて式(3)によってボ イド率を定義した.

$$
\alpha_{g, I}=\min \left(1, \frac{1}{S_{\mathrm{mesh}, I}} \sum_{j=1}^{N_{\mathrm{p}}} \sigma_{I j} S_{g, j}\right)
$$

ここで, 添え字 $I$ およ゙ $j$ はそれぞれ空間メッシュ番号と粒子番号, $S_{\mathrm{g}}\left[\mathrm{m}^{2}\right]$ は粒子面積, $S_{\mathrm{mesh}}\left[\mathrm{m}^{2}\right]$ はメッシュ面積, $N_{\mathrm{p}}\left[\right.$ - ] は全粒子数を表す。また， $\sigma_{I j}$ は粒子 $j$ の中心座標がメッシュ $I$ に含まれるときに 1 ，それ以外の場合 0 を返 寸関数である. したがって, 式(3)における総和はメッシュ $I$ に存在する気相の面積を意味する. ただし, $\min ($ ) によって切り捨てられた分は, あくまでボイド率評価において計上しないだけで, 粒子自体の面積を減らすこと はしない，併せて本手法では簡単のため， $\rho_{g}$ および $S_{g}$ は初期值で一定としており，噴出孔あるいは解析体系境界 以外では生成・消滅しない. よって, そのような流入, 流出を除いて気相の質量は保存される.

式 (1) 右辺第 3 項は粒子一伝熱管相互作用力 $\mathbf{f}_{\mathrm{pt}}[\mathrm{N} / \mathrm{kg}]$ である. これは, 伝熱管近傍で気相粒子に対して与えら れる影響を管周辺に広がるポテンシャルとしてモデル化したものである.この領域で流体に影響を与える要素と して圧力勾配力が重要と考えられる. Moving Particle Simulation（MPS）などでは粒子間相互作用の重㸚合わせに よって圧力勾配力を評価しているが，本研究では，粒子間相互作用評価に必要な粒子探索の計算コストがボトル ネックとなることを危惧して, 粒子探索を必要としない方法を検討した. 以下では, 伝熱管近傍に生じるポテン シャルとこれによる力 $\mathbf{f}_{\mathrm{pt}}$ として, 粒子の運動エネルギーに注目したモデルと, 単管周りの定常的な圧力場の理論 解に注目したモデルの 2 種類について述べる。 また, 粒子間相互作用評価を行わない設計のため, 本手法では粘 性がジェット挙動に与える影響を評価できていない. 現在のところは, 計算コストへの懸念と, ジェット挙動に 対して水蒸気内の粘性より $\mathrm{Na}$ との相間抗力の方が支配的であろうという考えから, エンジニアリングジャッジ により粘性による影響を無視した。

\section{$2 \cdot 2$ 運動エネルギーモデル}

以下のモデル説明において, 図 3 に示すように伝熱管中心位置を原点とする極座標系を考え, 粒子の位置ベク トルを $\mathbf{r}[\mathrm{m}]$, 伝熱管半径を $r_{t}[\mathrm{~m}]$, 伝熱管壁面から粒子中心までの距離を $l=|\mathbf{r}|-r_{t}[\mathrm{~m}]$ と表す.

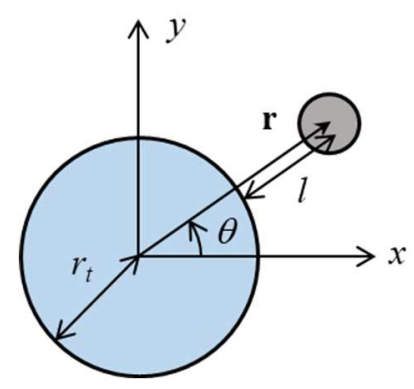

Fig. $3 x-y$ Cartesian and $r$ - $\theta$ polar coordinate system around a heat transfer tube. A blue larger circle represents a heat transfer tube, and a gray smaller circle does gas particle. $r_{t}$ is a radius of the tube, and $l=|\mathbf{r}|-r_{t}$ is a distance between the particle center and the surface of the tube. 
流体が管壁へ向かって流れているとき，管壁へ近づくにつれて管壁方向の流速が減少し，壁面上では 0（管内 部に入り込まない）となる．この点に注目し，壁面に到達するまでに相互作用力がする仕事 $\left(f_{e} l[\mathrm{~J} / \mathrm{kg}]\right)$ と流体の 半径方向速度 $u_{r}[\mathrm{~m} / \mathrm{s}]$ による運動エネルギー $\left(u_{r}^{2} / 2\right)$ が釣り合うとして力 $f_{e}[\mathrm{~N} / \mathrm{kg}]$ を決定した.

$$
f_{e}=\frac{u_{r}^{2}}{2 l}
$$

ただし，この力は粒子が管中心に向かって移動している場合 $\left(u_{r}<0\right)$ のみ作用させる. また，式(4)が発散して非 物理的な力を与える場合 $(l \sim 0)$ に備えて, 粒子に加えられる PT 相互作用力の大きさ $f_{\mathrm{pt}}=\left|\mathbf{f}_{\mathrm{pt}}\right|[\mathrm{N} / \mathrm{kg}]$ に対し, 完 全弾性衝突に相当する力を上限とする式(5)による制限を設けた。

$$
f_{\mathrm{pt}} \Delta t=\min \left(\left|f_{e}\right| \Delta t,\left|2 u_{r}\right|\right)
$$

ここで， $\Delta t[\mathrm{~s}]$ は時間刻み幅である.

\section{$2 \cdot 3$ 圧力場モデル}

噴出後しばらくすると反応ジェットのボイド率や温度は, 細かなゆらぎはあるが, 定常的な分布を持つように なる．伝熱管破断の予測には，持続的にジェットが衝突する位置や高温領域を評価することが重要である. 本モ デルでは, 十分に発達した後の流れ場を求めることを考え, 単管周りの圧力場の定常解をべースとして, 実効的 な圧力場を与えることを検討した．管群体系への拡張の方針として，手始めとして最も単純に，体系内すべての 伝熱管に同様の圧力場を設定する方針を検討しているが，まず本論文では次節のテスト解析により，本モデルの 単ターゲット管体系における基本的な機能を確認する.

円筒周りの均一な非圧縮性流れにおいて生じる圧力場の解析解（今井，1973）を式(6)に示寸．伝熱管周りに同 様の圧力場が形成されるとみなし，粒子に対する圧力勾配による力 $\mathbf{f}_{\mathrm{pt}}=-\left(1 / \rho_{g}\right) \nabla p$ を評価した.

$$
p(r, \theta)=\frac{1}{2} \rho_{g} v_{\text {flow }}^{2}\left\{2 \frac{r_{t}^{2}}{r^{2}} \cos \left[2\left(\theta-\frac{\pi}{2}\right)\right]-\frac{r_{t}^{4}}{r^{4}}\right\}+P_{\infty}
$$

ここで, $r[\mathrm{~m}]$ は位置ベクトル $\mathbf{r}$ の大きさを表す. $\theta[\mathrm{rad}]$ は角度を表し, 図 3 に示すように $x$ 軸上を 0 として反時計 回りを正に取る。 $P_{\infty}[\mathrm{Pa}]$ は十分遠い位置における圧力で一定值とし, 粒子に作用寸る力は式(6)の勾配であるため, 具体的な值を設定しない. $v_{\text {flow }}[\mathrm{m} / \mathrm{s}]$ は解析解においては十分離れた位置での一様流速を意味するが，本モデルに おいては相互作用力の大きさを左右するモデルパラメータである. 次節で示すテスト解析結果では何度かの予備 解析を通して経験的に $v_{\text {flow }}$ を決定しており, 解析条件に応じて適切に決定する方法については今後検討を要する. 式(6)の波括弧内第 1 項は管周りでの角度に依存した圧力変化を意味しており, 粒子に作用する半径方向の力とし

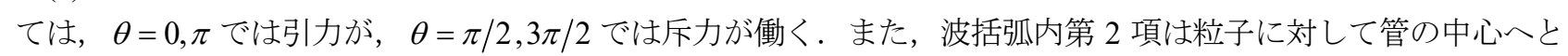
向かう定常的な引力を与える.

粒子が管内部一侵入した場合（ $l<r_{g}, r_{g}[\mathrm{~m}]$ は粒子半径 $)$ には，粒子位置を壁面上に戻し，速度方向を壁面の接 線方向へ変更する処理を行った。 これにより粒子が伝熱管境界より内側に存在する状況や, 粒子位置が伝熱管中 心と一致した場合 $(r=0)$ に生じる計算の破綻が回避される.

\section{3. 単ターゲット管体系を課したテスト解析}

\section{$3 \cdot 1$ 初期条件}

運動エネルギーモデルと圧力場モデルの基本的な機能検証のため, 図 4 に示寸ような 2 次元体系でテスト解析 を実施した. 寸なわち，位置 $\left(x_{0}, y_{0}\right)=(0,0.0159)$ [m]を中心とする直径 $D_{0}=0.01[\mathrm{~m}]$ の噴出孔から速さ $v_{0}=100[\mathrm{~m} / \mathrm{s}]$ で水蒸気が鉛直上向き $\left(\theta_{0}=\pi / 2[\mathrm{rad}]\right)$ に噴出させた．なお，ボイド率定義のため，解析領域を $11 \times 21$ に等分割 した. 相間抗力評価のための Autruffe モデルでは, 引用元である SERAPHIM の検証解析で用いられた $D_{h}=0.0732$ 
を本粒子法のテスト解析でも採用した．実機規模の試験解析（田辺，渡辺，1986）の試験条件を参考に，気相お よび夜相の温度をそれぞれ $347\left[{ }^{\circ} \mathrm{C}\right], 459\left[{ }^{\circ} \mathrm{C}\right]$, また圧力をともに $0.15[\mathrm{MPa}]$ と設定し, 密度はそれぞれ $\rho_{g}=0.526$ $\left[\mathrm{kg} / \mathrm{m}^{3}\right], \quad \rho_{l}=869\left[\mathrm{~kg} / \mathrm{m}^{3}\right]$ で一定值とした.

解析時間 $t_{\mathrm{end}}=1[\mathrm{~s}]$ までに噴出孔より流入する水蒸気質量と, 粒子質量の総和が等しいとして, 式(7)の関係を課 す.

$$
\rho_{g} v_{0} t_{\text {end }} D_{0}=N_{\mathrm{p}} \rho_{g} S_{g}
$$

粒子総数を $N_{\mathrm{p}}=10^{5}$ として, 式(7)により粒子面積 $S_{g}$ を決定した.

本テスト解析では粒子間相互作用を与えていないため, 解析条件として与えた噴出孔位置および速度だけでは すべての粒子が同じ軌道を通ってしまう。これを避けるため粒子それぞれの初期位置 $\left(x_{\mathrm{ini}}, y_{\mathrm{ini}}\right)$ および初速度方向 $\theta_{\mathrm{nin}}$ について, -0.5 から 0.5 の一様乱数 $R$ を用いて次式(8), (9)により決定した.

$$
\begin{aligned}
& \left(x_{\mathrm{ini}}, y_{\mathrm{ini}}\right)=\left(\frac{D_{0}}{2} R, 0.0159\right) \\
& \theta_{\mathrm{ini}}=\frac{\pi}{2}+R \sin ^{-1}\left(\frac{D_{0}}{2 r_{t}}\right)
\end{aligned}
$$

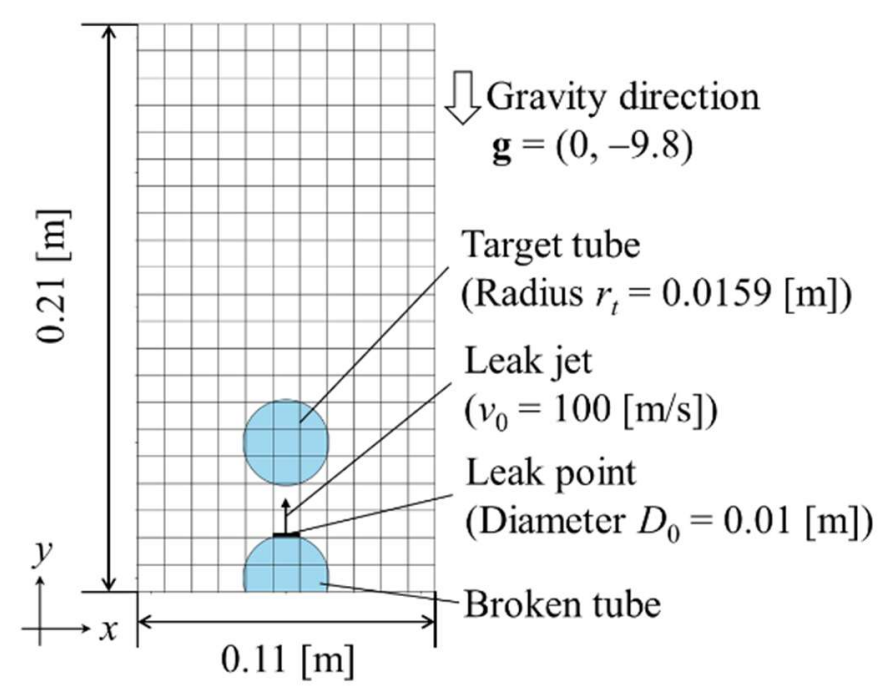

Fig. 4 Analysis area. In order to define void fraction distribution, this area is divided into $11 \times 21$ meshes. The vapor jet was discharged from the leak point $\left(x_{0}, y_{0}\right)=(0,0.0159)[\mathrm{m}]$, which is located on the surface of the broken tube. The magnitude of the initial jet velocity was $v_{0}=100[\mathrm{~m} / \mathrm{s}]$, and its angle was $\pi / 2[\mathrm{rad}]$ from the $x$-axis. The center positions of the broken and target tubes are $(0,0)$ and $(0,0.05)[\mathrm{m}]$, respectively. The radius of both tubes is $0.0159[\mathrm{~m}]$.

\section{$3 \cdot 2$ 解析結果}

粒子位置分布の時間発展を図 5 に示す，運動エネルギーモデル，圧力場モデルのどちらにおいても，水蒸気が ターゲット管を避けながら上昇する挙動が模擬できた. 圧力場モデルの $0.5[\mathrm{~ms}]$ 時において粒子が管内部に入り込 んでいる様子が見られるが，上述した粒子侵入時に壁面上まで位置を戻す処理により，管内に粒子がとどまり続 ける状況は回避されている. $2.5[\mathrm{~ms}]$ および $5.0[\mathrm{~ms}]$ において両モデルの差異を確認できる. 運動エネルギーモデル ではターゲット管後方にかけて粒子が二方向に分離している一方で, 圧力場モデルでは粒子が管表面上に引き付 けられている様子が確認できる，運動エネルギーモデルでは，伝熱管へ近づく粒子の半径方向速度を減じるのみ 
であり，粒子進行方向が分離されたのちは，粒子に対し浮力と気液相間抗力のみが作用するためである。一方で 圧力場モデルでは，圧力勾配力と管内部への粒子侵入を妨げる処理によって粒子進行方向が分離されたのちも粒 子に対して引力が作用しているため, 管の後方で粒子が回り込む挙動を示した. 10.0[ms]ではどちらのモデルで も，管より十分離れた粒子がそのまま浮力方向へ移動している様子が確認できる.

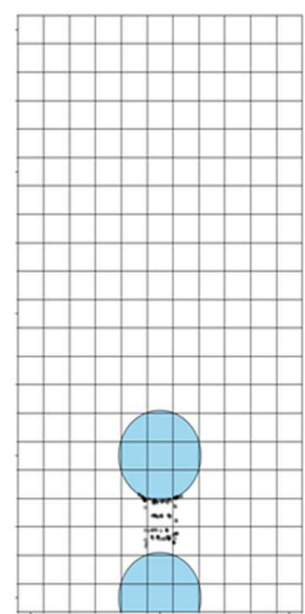

$0.5[\mathrm{~ms}]$

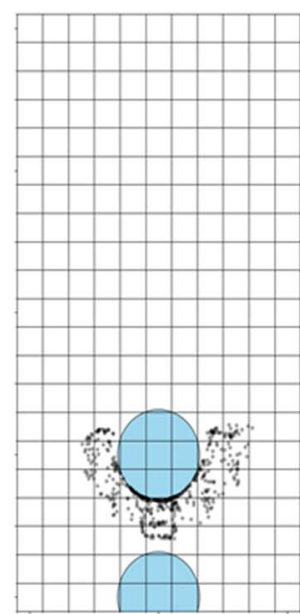

$2.5[\mathrm{~ms}]$

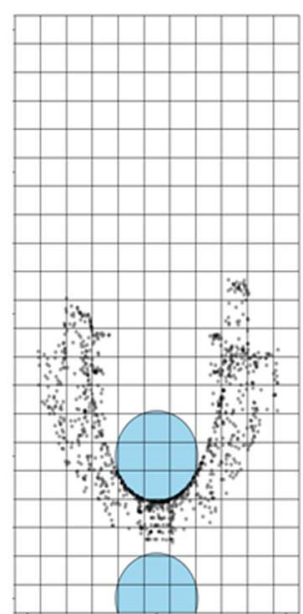

$5.0[\mathrm{~ms}]$

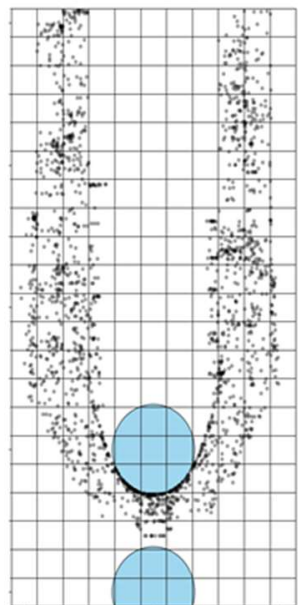

$10.0[\mathrm{~ms}]$

(a) Kinetic energy model

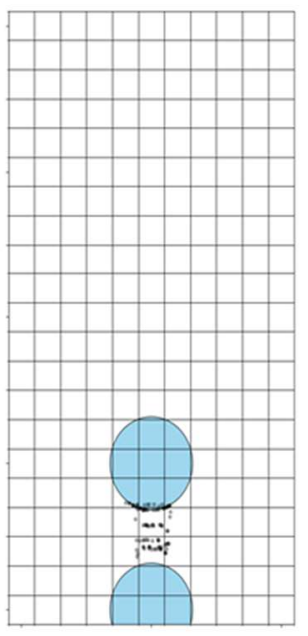

$0.5[\mathrm{~ms}]$

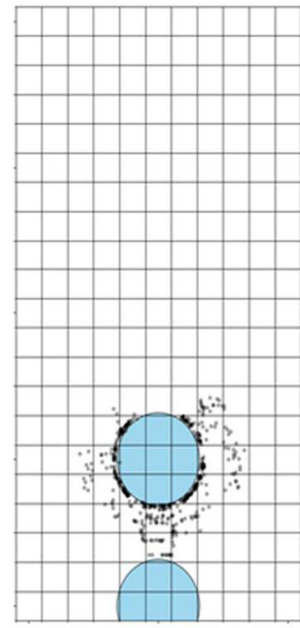

$2.5[\mathrm{~ms}]$

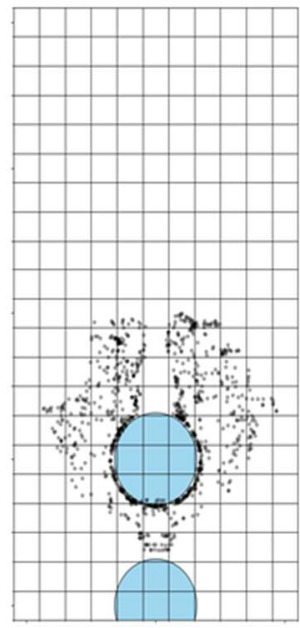

$5.0[\mathrm{~ms}]$

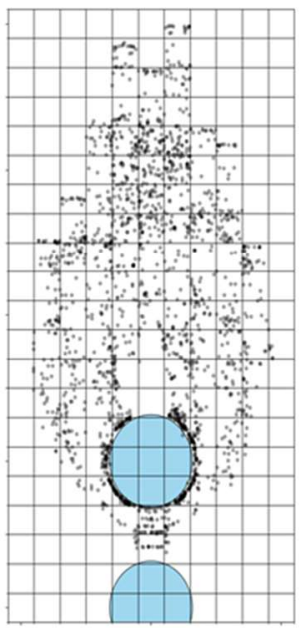

$10.0[\mathrm{~ms}]$

(b) Pressure model

Fig. 5 Time development of the particle distributions. In both models, the particles spread out around the target tube without significant inflow into the tube inside, and finally these went along the buoyancy force direction. The difference between the two models can be seen from 2.5 to $5.0[\mathrm{~ms}]$. In the kinetic energy model, the flow is divided by the tube and does not merge. In the pressure model, on the other hand, some particles move behind the tube.

ボイド率について，参照解として SERAPHIM による結果と，運動エネルギーモデルおよび圧力場モデルによ る解析結果を図 6 に示寸。ここで，ボイド率として，水蒸気が体系の上端に達し，流れの摇動も治まったと判断 した時点から時間平均したものを示した.

参照解において，噴出孔近傍にて初期速度方向（+y 方向）へ流れが進行したほか， $x$ 方向にも巻き込むように 気相が分布したが，これは噴出孔の縁で生じる渦によるものである. 粒子法側では渦を模擬するモデルは取り入 れていないため，噴出直後はそのまま+y方向へ気相分布が広がった. 
運動エネルギーモデルにおいて，図 5(a)と同様に，ボイド率としてもターゲット管後方にかけて分布が二方向 に分離された．参照解では，ボイド率分布が同様に分離されるが管壁面から大きくは離れずに高いボイド率を維 持したまま, 後流で合流している.この点, 圧力場モデルでは粒子が管の後方に回り込むために, 参照解に比較 的近いボイド率分布が得られた．ただし，管後方の壁面近傍では局所的にボイド率の低い領域が形成された。こ れは, 式(6)より $\theta=\pi / 2[\mathrm{rad}]$ で圧力勾配が周方向に関して極大值を取ることに加え, 浮力と相間抗力により運動方 向が浮力方向へ統一されつつあるので, 回り込んできた粒子はこの圧力勾配を乗り越えるほどの周方向運動エネ ルギーを持たないためである.

どちらもモデルにおいても，ターゲット管の前方に広がる気液界面をやや過大に評価している．今後，流体が 管壁面に沿うように動くことに注目したモデル改良を行うことで，粒子がより管周りに保持されるようになり， 管後流の流動をより適切に模擬できるほか気液界面としてもより妥当な結果が得られると期待される.

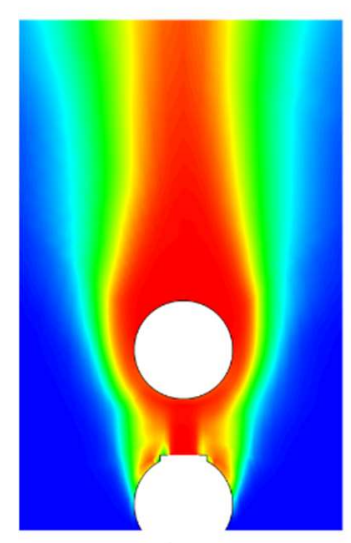

Reference (SERAPHIM)

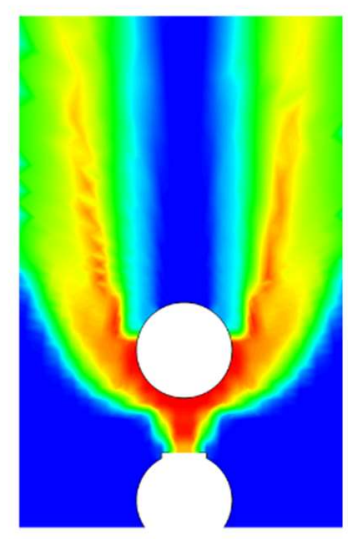

Kinetic energy model

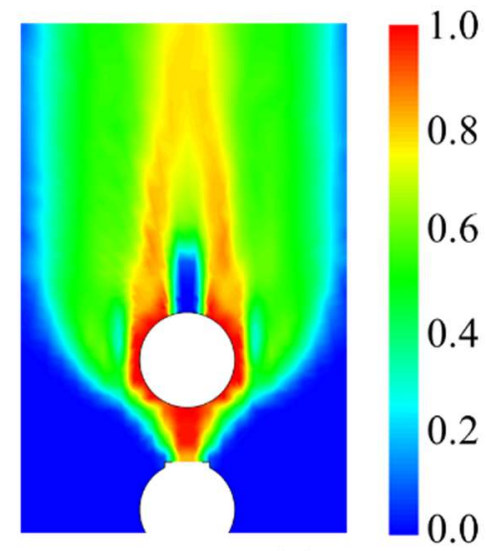

Pressure model

Fig. 6 Void fraction distribution. In the kinetic energy model, the void fraction distribution is separated by the tube. In the pressure model, there is a region of high void fraction around behind the tube. On the other hand, the void fraction is zero directly behind the tube. It is also shown that the gas-liquid interface is widely evaluated in both models.

以上より, どちらのモデルについても，管後流の挙動について改善の余地があるものの，管を避けながら浮力 方向へ移動するという基本的な流体挙動とボイド率分布を模擬できた。今後は実機条件に近い高流速条件

$(500[\mathrm{~m} / \mathrm{s}]$ 程度）の場合および管群体系の場合について, 同様にテスト解析と CFD コードとの比較を実施して, 本論文で提案した粒子一伝熱管相互作用モデルの実機条件適用性について検討する.これらの後, $\mathrm{Na}$ 一水反応評 価モデルなどと組み合わせて最終的な温度分布を評価し，本粒子法の総合的な機能を確認する.

\section{4. 結言}

伝熱管破損伝播解析コード LEAP-III における温度分布評価モデルの高度化に資する目的で, 工学的近似により 要素現象をモデル化した粒子法コードを開発した．本論文では，伝熱管近傍での流体挙動を粒子運動で模擬する ための新たな粒子一伝熱管相互作用モデルを提案し，単管体系にてテスト解析を実施した．解析結果を多次元多 相流 CFD コード（SERAPHIM）の結果と比較して，モデルの基本的な機能を確認した．今後は管群体系および 高流速条件に対してもテスト解析を実施し，実機条件への適用性を確認する.

\section{文献}

Autruffe, M. I., Wilson, G. J., Stewart, B. and Kazimi, M. S., A proposed momentum exchange coefficient for two-phase modeling of sodium boiling, International meeting on fast reactor safety technology (1979), pp.2512-2521.

今井功, 流体力学 (前編), 裳華房 (1973), pp. 120-122. 
Kosaka, W., Uchibori, A., Yanagisawa, H., Takata, T. and Jang, S., Numerical evaluation of sodium-water reaction based on engineering approach with particle method, Proceedings of 28th International Conference on Nuclear Engineering (ICONE28) (2021).

根井弘道, 堀雅夫, 小リーク $\mathrm{Na}$ 一水反応によるウェステージ現象 (反応温度とウェステージ分布), 日本機械学 会論文集 (第 2 部)，43 巻，368 号 (1977), pp 1418-1425.

高田孝, 山口彰, 橋本昭彦, 化学反応を含む多成分・多相流数值解析手法の開発一多次元ナトリウム一水反応解析 コード SERAPHIM-, JNC TN9400, 2001-125 (2002), p. 86.

田辺裕美, 渡辺智夫, 蒸気発生器安全性総合評価試験装置 (SWAT-3) による破損伝播試験 (V), PNC-TN9410, 86-104 (1986).

Uchibori, A., Takata, T., Shiina, Y. and Watanabe, A., Application of unstructured mesh-based sodium-water reaction analysis code SERAPHIM, Proceedings of 18th International Topical Meeting on Nuclear Reactor Thermal Hydraulics (NURETH-18) (2019), pp.5315-5324.

内堀昭寛, 柳沢秀樹, 高田孝, 栗原成計, 浜田広次, 大島宏之, 蒸気発生器における伝熱管破損時長時間事象進展 解析コード LEAP-III の開発, JAEA-Research 2017-007 (2017), DOI: 10.11484/jaea-research-2017-007.

Uchibori, A., Yanagisawa, H., Takata, T., Li, J. and Jang, S., Advancement of elemental analysis model in LEAP-III code for tube failure propagation, Mechanical Engineering Journal, Vol.7, No.3 (2020), DOI:10.1299/mej.19-00548.

\section{References}

Autruffe, M. I., Wilson, G. J., Stewart, B. and Kazimi, M. S., A proposed momentum exchange coefficient for two-phase modeling of sodium boiling, International meeting on fast reactor safety technology (1979), pp.2512-2521.

Imai, I., Fluid Dynamics Vol I, Shokabo (1973), pp. 120-122 (in Japanese).

Kosaka, W., Uchibori, A., Yanagisawa, H., Takata, T. and Jang, S., Numerical evaluation of sodium-water reaction based on engineering approach with particle method, Proceedings of 28th International Conference on Nuclear Engineering (ICONE28) (2021).

Nei, H. and Hori, M., Wastage phenomena by small leak sodium-water reaction (reacting temperature and wastage distribution), Transactions of the Japan Society of Mechanical Engineers (2nd), Vol.43, No.368 (1977), pp.1418-1425 (in Japanese).

Takata, T., Yamaguchi, A. and Hashimoto, A., Development of multi components and multi phase numerical method with chemical reaction - SERAPHIM: a multi-dimensional sodium water reaction analysis code-, JNC TN9400, 2001-125 (2002), p. 86 (in Japanese).

Tanabe, H. and Watanabe, T., Results of failure propagation tests in the steam generator safety test facility (SWAT-3) report no. 5, PNC-TN9410, 86-104 (1986) (in Japanise).

Uchibori, A., Takata, T., Shiina, Y. and Watanabe, A., Application of unstructured mesh-based sodium-water reaction analysis code SERAPHIM, Proceedings of 18th International Topical Meeting on Nuclear Reactor Thermal Hydraulics (NURETH-18) (2019), pp.5315-5324.

Uchibori, A., Yanagisawa, H., Takata, T., Kurihara, A., Hamada, H. and Ohshima, H., Development of LEAP-III code for evaluation of long-time event progress under tube failure accident in steam generators, JAEA-Research 2017-007 (2017), DOI: 10.11484/jaea-research-2017-007 (in Japanese).

Uchibori, A., Yanagisawa, H., Takata, T., Li, J. and Jang, S., Advancement of elemental analysis model in LEAP-III code for tube failure propagation, Mechanical Engineering Journal, Vol.7, No.3 (2020), DOI:10.1299/mej.19-00548. 